\title{
Partial deletion of chromosome $6 p$ causing developmental delay and mild dysmorphisms in a child: molecular and developmental investigation and literature search
}

\author{
Nikolaos Vrachnis ${ }^{1,2,3^{*}}$ (D), loannis Papoulidis ${ }^{4}$, Dionysios Vrachnis ${ }^{5}$, Elisavet Siomou ${ }^{4}$, \\ Nikolaos Antonakopoulos ${ }^{1,2}$, Stavroula Oikonomou ${ }^{6}$, Dimitrios Zygouris ${ }^{2}$, Nikolaos Loukas ${ }^{7}$, Zoi lliodromiti ${ }^{8}$, \\ Efterpi Pavlidou ${ }^{9}$, Loretta Thomaidis ${ }^{6}$ and Emmanouil Manolakos ${ }^{4}$
}

\begin{abstract}
Background: The interstitial 6p22.3 deletions concern rare chromosomal events affecting numerous aspects of both physical and mental development. The syndrome is characterized by partial deletion of chromosome 6 , which may arise in a number of ways.

Case presentation: We report a 2.8-year old boy presenting with developmental delay and mild dysmorphisms. High-resolution oligonucleotide microarray analysis revealed with high precision a $2.5 \mathrm{Mb}$ interstitial $6 \mathrm{p}$ deletion in the 6 p22.3 region which encompasses 13 genes.
\end{abstract}

Conclusions: Identification and in-depth analysis of cases presenting with mild features of the syndrome will sharpen our understanding of the genetic spectrum of the 6p22.3 deletion.

Keywords: 6p22.3 deletion, Syndrome, Developmental delay, Intellectual disability, Dysmorphism, Behavioral abnormalities, High-resolution microarray analysis

\section{Background}

The interstitial deletion of chromosomal region $6 \mathrm{p} 22.3$ is a rare condition with variable phenotypic expression. To date, more than 30 children and adolescents with this deletion have been reported [1-11]. Interestingly, Colmant et al. described an electively aborted fetus with multiple abnormalities presenting the same deletion [12]. According to the size of the 6 p22.3 deletion, which usually varies between 1 and $10 \mathrm{MB}[3,4]$, the clinical manifestations may include behavioral abnormalities,

\footnotetext{
*Correspondence: nvrachnis@hotmail.com

1 Third Department of Obstetrics and Gynecology, National

and Kapodistrian University of Athens, Medical School, Attikon Hospital, Athens, GR, Greece

Full list of author information is available at the end of the article
}

dysmorphic features, and structural organ defects, as well as intellectual disability.

We report herein a case of interstitial deletion of chromosome $6 \mathrm{p}$ investigated by array-CGH in a 2.8 -year old boy with developmental delay, mild facial dysmorphism, and speech communication disorders.

\section{Case presentation}

The patient was a 2.8-year old boy born to non-consanguineous healthy parents after an uncomplicated fullterm pregnancy. He is the third child of the family, the other two offspring being a healthy 8-year old boy and a healthy 10 -year old girl. He was born by cesarean section with birth weight $2.990 \mathrm{~g}$ (15th centile), length $50 \mathrm{~cm}$ original author(s) and the source, provide a link to the Creative Commons licence, and indicate if changes were made. The images or other third party material in this article are included in the article's Creative Commons licence, unless indicated otherwise in a credit line to the material. If material is not included in the article's Creative Commons licence and your intended use is not permitted by statutory regulation or exceeds the permitted use, you will need to obtain permission directly from the copyright holder. To view a copy of this licence, visit http://creativecommons.org/licenses/by/4.0/. The Creative Commons Public Domain Dedication waiver (http://creativeco mmons.org/publicdomain/zero/1.0/) applies to the data made available in this article, unless otherwise stated in a credit line to the data. 
(35th centile), and head circumference $34 \mathrm{~cm}$ (15th centile). His perinatal history was uneventful.

His motor milestones in infancy and toddlerhood are reported as normal, as he sat unsupported at the age of 6 months and walked unaided at the age of 15 months. At the age of 13 months, bilateral cryptorchidism was surgically corrected.

Due to speech and language delay, he was referred at the age of 2 years and 8 months for a full developmental assessment. On physical examination, he was found to be a sociable child with mild dysmorphic facial and body features, including frontal bossing, micrognathia, short thin nose, small deep-set eyes, small mouth with long flat philtrum, low-set ears with auricle abnormalities, widely spaced nipples, broad thumbs, and long tapering fingers. Developmental assessment showed that the child had good pretend play ability; however, verbal expression was lacking, while his comprehension was limited to simple commands. His overall developmental level was equivalent to that of a healthy 15-month old child, which corresponds to low developmental quotient $(\mathrm{DQ}=40)$. On neurological examination, he showed global hypotonia of trunk and limbs without focal neurological signs. His height was $95 \mathrm{~cm}$ (50th centile), his weight was $15 \mathrm{~kg}$ (50th centile), and his head circumference was $51 \mathrm{~cm}$ (30th centile). Laboratory investigation, including audiological, visual, biochemical, metabolic, endocrine (thyroid, growth hormone, luteinizing hormone, folliclestimulating hormone, adrenocorticotropin hormone and prolactin), bone age, and kidney/liver and triplex ultrasound assessments were normal. Brain MRI (magnetic resonance imaging) showed bilateral choroid plexus cysts, with a bigger cyst on the left and areas of increased signal intensity in periventricular white matter along the lateral horns of both lateral ventricles and along the frontal horns, this probably related to late myelination.
High-resolution molecular karyotyping was performed with an aCGH platform of 60,000 oligonucleotides (Agilent Technologies, Santa Clara, Cal., USA) at the age of 2 years and 8 months [ISCN formula: $\operatorname{arr}$ [GRCh37] 6p22.3 (15,794,379_18,277,334)x1dn]. DNA extracted from blood lymphocytes showed that the $6 \mathrm{p}$ deletion was a $2.5 \mathrm{Mb}$ deletion of the distal short arm of chromosome 6 with the proximal breakpoints between 15,794,379 bp (last deleted oligo) and 15,793,879 bp (first normal oligo), and the distal breakpoints between 18,291,461 bp (first normal oligo), and 18,277,334 bp (last deleted oligo) (Fig. 1).

Chromosome analysis with banding patterns, using GTG-banding techniques, was also carried out on stimulated blood lymphocytes and analyzed at 550-600 band resolution. Cytogenetics revealed a normal karyotype. Again, the parental karyotypes (blood lymphocytes) were normal, as produced by using banding patterns.

\section{Discussion}

Deletions of $6 \mathrm{p}$ chromosome are a group of heterogeneous chromosomal anomalies. There is variability in the size and location of the breakpoints, resulting in diverse and overlapping clinical phenotypes, depending on the genes located in the deleted areas. Consequently, making an accurate genotype-phenotype correlation is often challenging. $6 \mathrm{p}$ deletions can involve either the distal or the interstitial part of the short arm of chromosome 6 .

Deletions involving the distal part of the short arm of chromosome 6 are relatively rare. Terminal deletions of 6p24-pter have been associated with developmental delay, brain malformations (including Dandy-Walker malformation), anterior eye chamber abnormalities, hearing loss, ear abnormalities, micrognathia, and heart defects. Patients with larger sized deletions of 6p23pter also present with microcephaly, genital anomalies,

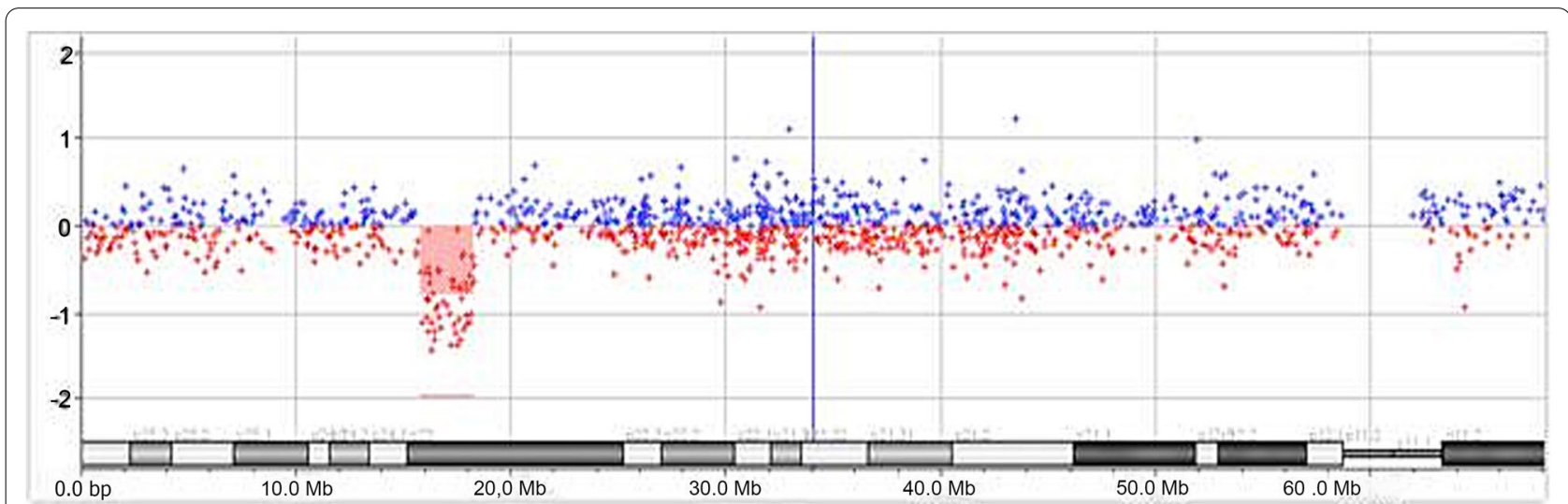

Fig. 1 Array-CGH analysis illustrating in depth the de novo interstitial microdeletion of approximately $2.5 \mathrm{Mb}$ in size on the short arm of chromosome 6 at chromosomal band 6p22.3, chr6: 15,794,379 to 18,277,334, using build GRCh37 (hg19) 
language impairment, and delayed motor development [11-18].

Interstitial deletions of $6 \mathrm{p} 22-\mathrm{p} 24$ have been reported even less often. Our patient had an interstitial deletion of about $2.5 \mathrm{Mb}$ in chromosomal band $6 \mathrm{p} 22.3$. Some of the aforementioned reports concern deletions with different breakpoints which do not overlap with our case, thus exhibiting a different phenotype. For example, there is a report of four patients with a $6 \mathrm{p} 22.3$ deletion located more proximally in comparison with our case. Three of them had mesomelic dysplasia and the fourth (who had a larger deletion) had developmental delay without skeletal anomalies [19]. Ladinsky et al. also reported a patient with skeletal abnormalities (lower extremity hemimelia with mesomelic shortening), facial dysmorphisms, sensorineural hearing loss, and cardiac and renal abnormalities. This patient had a $6 \mathrm{p} 22.3$ deletion located from positions 20, 019, 758 to 21, 784, 966 [20].

Our patient presented with developmental delay and mild dysmorphisms. This phenotype is consistent with the clinical spectrum of other $6 \mathrm{p} 22.3$ overlapping deletions reported in the literature and comprises psychomotor delay, intellectual disability, behavioral abnormalities, dysmorphic facial features, defects in brain, heart, kidney and eye development, short neck, clinodactyly, and syndactyly.

The deleted region in our patient encompasses 13 genes, namely, ATXN1 (ataxin-1 gene), CAP2 (cycliseassociated actin cytoskeleton regulatory protein 2 gene),
DEK (DEK proto-oncogene), FAM8A1 (family with sequence similarity 8 , member A1), GMPR (guanosine monophosphate reductase gene), KDM1B (lysine demethylase 1B), KIF13A (kinesin family member 13A gene), MYLIP (myosin regulatory light chain interacting protein gene), NHLRC1 (NHL repeat containing E3 ubiquitin protein lipase 1 gene), NUP153 (nucleoporin 153 gene), $R M B 24$ (RNA binding motif protein 24 gene), STMND1 (stathmin domain containing 1 gene), and TPMT (thiopurine S-methyltransferase gene) (Table 1).

In the literature, there are several reports of $6 \mathrm{p} 22.3$ deletions which overlap with the deleted region of our patient. Our search on the PUBMED database revealed 19 cases, while the DECIPHER database revealed 18 cases. Some of these patients were genetically investigated by using FISH analysis, without accurate mapping of the breakpoint borders, as the latter technique was not available at the time of their investigation. In the interim, advanced molecular technology, such as the use of array$\mathrm{CGH}$, has allowed more precise evaluations of the breakpoint borders and identification of the included genes. During the past decade, researchers have identified critical overlapping regions in the deleted areas which could be candidates for the $6 \mathrm{p} 22.3$ deletion phenotype (Fig. 2 and Table 2). Bremer et al. proposed a $2.2 \mathrm{Mb}$ minimal critical region involving 12 genes, while DiBenedetto et al. identified a $6 \mathrm{p}$ deletion of about $1 \mathrm{Mb}$, encompassing 5 genes $[1,2]$. Genome.ucsc.edu indicates that the most consistently implicated genes are MYLIP, GMPR,

Table 1 Clinical information for all cases carrying a 6p22.3 deletion overlapping with our case

\begin{tabular}{|c|c|c|c|c|c|c|c|c|c|c|c|c|c|c|c|c|c|c|c|c|}
\hline $\mathrm{Pt}$ & [1] & [2] & [3]a & [3]b & [3]c & [3]e & [3]f & [4]a & {$[4] \mathrm{b}$} & {$[4] \mathrm{c}$} & {$[4] \mathrm{d}$} & [4]e & {$[5] a$} & [6] & [7] & [8] & [9] & {$[10] 3$} & {$[10] 4$} & Pr.case \\
\hline Age & 4 & 18 & 15 & 4 & 0 & 7 & 3 & 15 & 4 & 6.5 & 6.5 & 17 & 15 & 15 & 11 & 0 & 3.6 & 2.5 & 5 & 7.6 \\
\hline Sex & $\mathrm{F}$ & $M$ & $M$ & M & $\mathrm{F}$ & $\mathrm{F}$ & M & $\mathrm{F}$ & $M$ & $\mathrm{~F}$ & $M$ & $\mathrm{~F}$ & $M$ & $\mathrm{~F}$ & $\mathrm{~F}$ & $M$ & $M$ & M & $M$ & $M$ \\
\hline Head & - & + & - & - & - & - & - & - & - & - & - & - & - & + & - & - & + & + & - & - \\
\hline Craniofacial dysmorphies & + & + & + & - & + & + & + & + & + & + & + & - & + & + & + & + & + & + & + & + \\
\hline Neck/chest & + & - & + & - & + & - & + & - & - & - & - & - & - & + & - & + & + & + & + & + \\
\hline Heart defect & + & - & - & na & + & - & + & - & + & - & - & - & - & + & - & - & + & - & - & + \\
\hline Respiratory & - & - & - & - & + & - & - & - & - & - & - & - & - & - & + & & + & - & - & - \\
\hline Abdomen & - & + & - & - & + & - & - & - & - & + & - & - & + & - & - & & + & - & + & - \\
\hline Gl & - & - & - & - & + & - & - & - & - & - & - & - & - & - & - & & - & - & - & - \\
\hline Kidney & - & - & - & - & - & - & - & - & - & - & - & - & - & + & + & + & - & - & - & - \\
\hline Genital & - & + & - & - & - & - & - & - & - & - & - & - & - & - & - & & - & + & - & - \\
\hline Skeletal & - & + & + & - & + & - & + & + & + & + & + & - & + & + & - & + & + & + & + & + \\
\hline Skin & - & - & + & - & + & - & - & - & - & - & - & - & + & + & - & & - & - & - & - \\
\hline CNS & - & + & na & na & na & - & + & + & - & - & - & - & na & - & - & + & + & + & - & - \\
\hline Hypotonia & - & + & - & - & + & - & + & - & - & + & + & - & + & - & - & & + & - & - & + \\
\hline DD/ID & + & + & + & + & & + & + & + & + & + & + & + & + & + & + & & + & + & + & + \\
\hline ASD & - & + & + & + & & - & - & - & - & + & - & - & - & - & - & & - & - & - & - \\
\hline ADHD & - & - & - & - & & - & - & - & - & + & - & - & - & - & - & & - & - & - & - \\
\hline Learning disorder & na & - & - & - & & na & + & + & na & + & na & + & + & na & na & & na & na & na & + \\
\hline
\end{tabular}




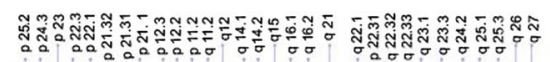

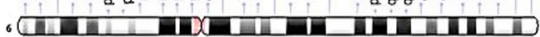

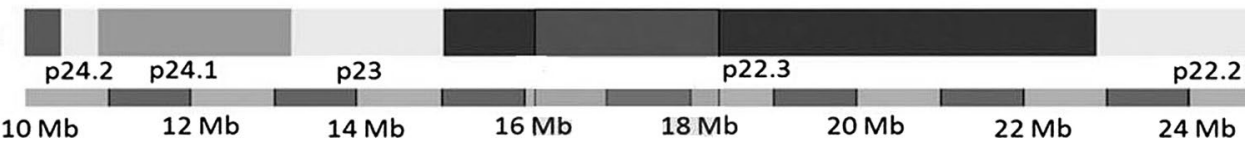

Fig. 2 Overlapping deletions cases. For cases [3]b, [3]c, [3]e, [3]f, [5]a, [7], [8], [9], [10]3, [10]4 (see Table 2) there were no available breaking points

Table 2 Cases carrying a 6p22.3 deletion overlapping with our case, sizes of the deletions and technique used

\begin{tabular}{|c|c|c|c|}
\hline Case & Deletion & Size of deletion & Technique used \\
\hline Present case & $6 p 22.3$ & $2.5 \mathrm{Mb}$ & ArrayCGH \\
\hline [1] & $6 p 22.3$ & $7.1 \mathrm{Mb}$ & ArrayCGH \\
\hline [2] & $6 p 22.3$ & $1 \mathrm{Mb}$ & ArrayCGH \\
\hline [3]a & $6 p 22.3-p 23$ & $5.4 \mathrm{Mb}$ & ArrayCGH \\
\hline$[3] \mathrm{b}$ & $6 p 22.3$ & $1 \mathrm{Mb}$ & ArrayCGH \\
\hline [3]c & 6p22.3-p24.3 & $14.6 \mathrm{Mb}$ & ArrayCGH \\
\hline [3]e & $6 p 22.3$ & $5.2 \mathrm{Mb}$ & ArrayCGH \\
\hline$[3] \mathrm{f}$ & 6p22.3-p24.1 & $8.8 \mathrm{Mb}$ & ArrayCGH \\
\hline$[4] \mathrm{a}$ & $6 p 22.3-p 24.1$ & $4.8-4.9 \mathrm{Mb}$ & ArrayCGH \\
\hline$[4] \mathrm{b}$ & $6 p 22.3-p 24.1$ & $3.1 \mathrm{Mb}$ & ArrayCGH \\
\hline$[4] \mathrm{C}$ & $6 p 22.3-p 24.1$ & $2.3-2.6 \mathrm{Mb}$ & ArrayCGH \\
\hline$[4] \mathrm{d}$ & $6 p 22.3-p 24.1$ & $189-241 \mathrm{~kb}$ & ArrayCGH \\
\hline [4]e & 6p22.3-p24.1 & $116-163 \mathrm{~kb}$ & ArrayCGH \\
\hline$[5] a$ & 6p22.1/p22.2-6p23 (FISH) & $15 \mathrm{Mb}$ & $\mathrm{FISH}$ \\
\hline [6] & $6 p 22.1-6 p 23$ & $13.3 \mathrm{Mb}$ & SNP oligonucleotide array \\
\hline [7] & $6 p 22.1-p 22.3$ & NA & ArrayCGH \\
\hline [8] & $6 p 22.3-p 24.3$ & $15.2 \mathrm{Mb}$ & ArrayCGH \\
\hline [9] & (pter-p23:p21.33-qter) or & & \\
\hline (pter-p25.2:p22.2-qter) & na & Classic karyotype & \\
\hline$[10] 3$ & $6 \mathrm{p} 22 \sim 24 \mathrm{p} 22 \sim 24$ & na & $\mathrm{FISH}$ \\
\hline$[10] 4$ & 6p22p24 & na & $\mathrm{FISH}$ \\
\hline
\end{tabular}

ATX1, NUP153, KIF13A, NHLRC1, TPMT, DEK, and JARID2 (Fig. 3). However, the deleted area of our patient did not include the latter gene. Apart from the number and type of genes involved in the deleted areas, other molecular mechanisms besides gene-dosage effects need to be considered in order to interpret the clinical phenotype. Such mechanisms could be the presence of modifiers in the non-deleted alleles, regulatory regions, or other genes elsewhere in the genome, as well as different penetrance or variable expressivity of $\mathrm{HI}$ of the deleted genes. Furthermore, the pLI score of the deleted genes, which shows intolerance to loss-of-function mutations thus indicating that haploinsufficiency of a specific gene could be responsible for clinical manifestations, should be taken into consideration. Finally, structural and quantitative chromosomal rearrangements, collectively referred to as structural variation (SV), contribute, to a large extent, to the genetic diversity of the human genome and thus are of high relevance for rare diseases, as well as for cancer and for evolutionary genetics. Recent studies have shown that SVs may not only affect gene dosage but also modulate basic mechanisms of gene regulation. SVs can alter the copy number of regulatory elements or modify the 3D genome by disrupting higher-order chromatin organization, such as topologically associated domains. As a result of these position effects, SVs can influence 


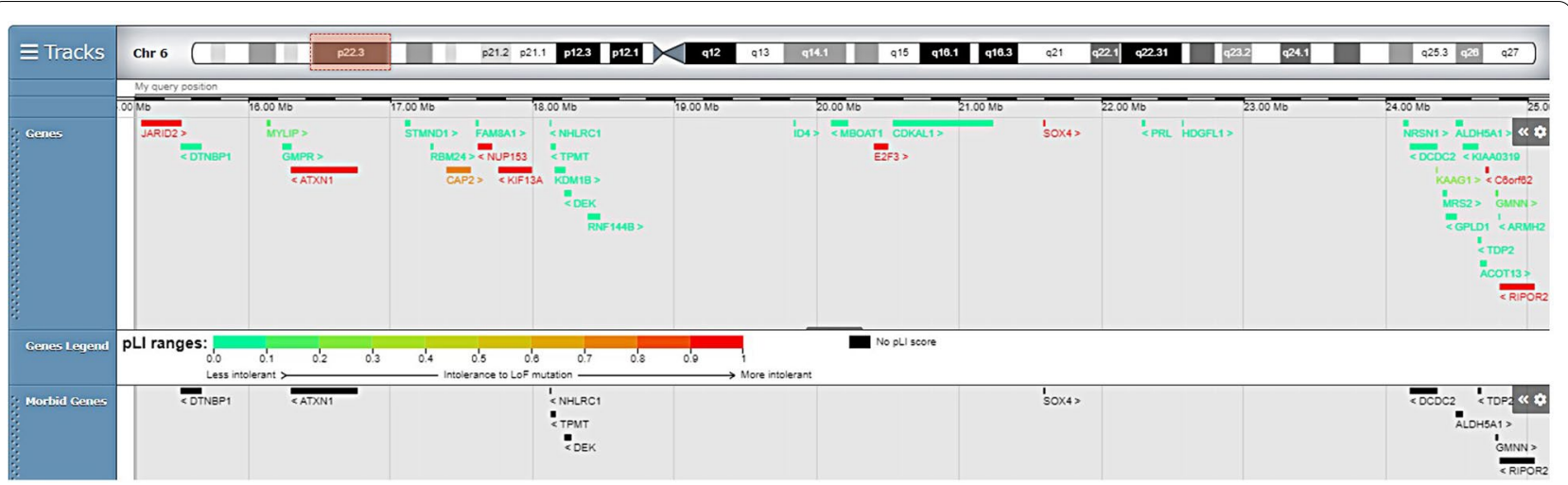

Fig. 3 Genes and gene predictions located in the deleted region are taken from https://decipher.sanger.ac.uk. The red box indicates the deleted region of the 6 p22.3 chromosome band

the expression of genes distant from the SV breakpoints, thereby causing disease. The impact of SVs on the 3D genome and on gene expression regulation must be considered when interpreting the pathogenic potential of these variant types [21].

A discussion of the proteins and their functions encoded by the deleted genes of our case follows, as it

Table 3 Summary of the genes included in the deleted area of our case. Function and disease association of the genes, pLI and haploinsufficiency score and OMIM number are provided

\begin{tabular}{|c|c|c|c|c|c|}
\hline Gene symbol & Function & Disease association & pLI score & $\begin{array}{l}\text { Haploinsufficiency } \\
\text { score }\end{array}$ & OMIM reference \\
\hline ATX1 & $\begin{array}{l}\text { RNA and protein binding; transcrip- } \\
\text { tional repressor activity }\end{array}$ & Spinocerebellar ataxia type 1 & 0.97 & 5,05 & 601,556 \\
\hline CAP2 & Actin-binding protein & Human hepatocellular carcinoma & 0.70 & 40,60 & 618,385 \\
\hline DEK & Chromatin-remodeling & $\begin{array}{l}\text { Cancer biology, autoimmune diseases, } \\
\text { cognitive function }\end{array}$ & 0.06 & 4,88 & 125,264 \\
\hline FAM8A1 & NA & NA & 0.02 & 59,65 & 618,409 \\
\hline GMPR & $\begin{array}{l}\text { Maintaining the intracellular balance of } \\
\mathrm{A} \text { and } \mathrm{G} \text { nucleotides }\end{array}$ & Progressive external ophthalmoplegia & 0.00 & 30,36 & 139,265 \\
\hline KDM1B & Lysine demethylase 1B & $\begin{array}{l}\text { Flavin-dependent histone dem- } \\
\text { ethylases regulate histone lysine } \\
\text { methylation, an epigenetic mark } \\
\text { that regulates gene expression and } \\
\text { chromatin function }\end{array}$ & 0.00 & 35,23 & 613,081 \\
\hline KIF13A & $\begin{array}{l}\text { Intracellular transport, neuronal signal } \\
\text { transduction }\end{array}$ & NA & 1.00 & 42,26 & 605,433 \\
\hline MYLIP & $\begin{array}{l}\text { Protein-protein interaction,cell signal- } \\
\text { ing, cholesterol metabolism, inhibi- } \\
\text { tion of neurite outgrowth }\end{array}$ & NA & 0.18 & 34,06 & 610,082 \\
\hline NHLRC1 & E3 ubiquitin ligase activity & Myoclonic epilepsy of Lafora & 0.09 & 57,05 & 608,072 \\
\hline NUP153 & $\begin{array}{l}\text { Mediate the regulated movement } \\
\text { of macromolecules between the } \\
\text { nucleus and cytoplasm }\end{array}$ & NA & 1.00 & 24,39 & 603,948 \\
\hline RMB24 & $\begin{array}{l}\text { Regulation of pre-mRNA splicing, } \\
\text { mRNA stability and mRNA translation } \\
\text { important for cell fate decision and } \\
\text { differentiation }\end{array}$ & NA & 0.09 & 41,96 & 617,605 \\
\hline STMND1 & NA & NA & 0.00 & 80,55 & NA \\
\hline TPMT & $\begin{array}{l}\text { S-methylation of aromatic and hetero- } \\
\text { cyclic sulphydryl compounds }\end{array}$ & NA & 0.00 & 65,83 & 187,680 \\
\hline
\end{tabular}


will shed light on the clinical, developmental, and other findings presented (see also Table 3 ).

Ataxin-1 protein (encoded by the ATX1 gene-OMIM $\# 601,556)$ is widespread in the normal human brain, mainly within neuronal nuclei, although some Purkinje cells exhibit minor cytoplasmic components. It has been shown that spinocerebellar ataxia type 1, through mutations of the gene, causes expansion of an unstable CAG trinucleotide repeat aggregation of the mutant protein and, ultimately, neurotoxicity and neurodegeneration. It has also been proposed that $A T X 1$ functions as a regulator of gene expression [22]. There are so far few experimental data on the effects of an absent or nonfunctional ataxin-1 protein. However, Matilla et al. reported that mice lacking ataxin-1 showed spatial learning deficits as well as motor coordination impairments [23]. Therefore, hemizygosity for ATX1 could contribute to the observed learning disabilities. A recent meta-analysis has additionally proposed that single nucleotide polymorphisms (SNPs) in ATXN1 may be linked to the lower than average intelligence quotient observed in ADHD [24]. Based on the fact that mouse models have shown ATXN1 to be of crucial importance for brain function (its absence giving rise to behavioral disorders), heterozygous deletions impacting ATXN1 function could well be involved in both developmental delay and in autism spectrum disorders, whether alone or in conjunction with other gene deletions [3].

MYLIP (OMIM \#610,082) is a novel ERM-like protein encoded by the MYLIP gene. It was determined that ERM-containing proteins, interacting with the cytoplasmic part of transmembrane proteins, connect these to the cytoskeleton in cell signaling. While playing an important role in the establishment of dynamic membrane structures, they also participate in regulation of cell proliferation, differentiation, and receptor signal transduction events [25]. MYLIP, in addition to having an amino-terminal ERM homology domain, also has a carboxyl-terminal RING finger: the latter is involved in regulating both the growth and survival of cells through ubiquitination [26]. A study of MYLIP expression during rat brain development showed that MYLIP is specifically localized to neuronal cells and is present in various brain regions, especially in the hippocampus and cortex. In humans, MYLIP is expressed in various tissues, including the brain. It has been observed that overexpression of MYLIP inhibits nerve growth factor-driven neurite outgrowth in neuronal PC12 cells through interaction with the myosin regulatory light chain [27]. MYLIP is also involved in cholesterol metabolism through regulation of the LDL receptor [28]. Given the presence of MYLIP in neuronal cells and its thus far identified functions in neurite outgrowth, it is reasonably hypothesized that the deletion of the MYLIP gene has profound effects on the neuronal cytoskeleton. Additionally, the abundant expression of MYLIP in almost all human tissues suggests further functions and targets for this protein.

The GMPR gene (OMIM \#139,265) encodes guanosine monophosphate reductase: this is an evolutionarily conserved enzyme from humans to bacteria which catalyzes the conversion of the ribonucleotide GMP to IMP, the latter being a precursor ribonucleotide for the synthesis of purine nucleotides. GMPR is found to be highly expressed in the cytosol of skeletal and cardiac myocytes and also in renal cells. To the best of our knowledge, there is only one report in the literature so far identifying a disease-causing mutation of the GMPR gene, this being the study by Sommerville et al. who identified a novel heterozygous GMPR variant as the cause of progressive external ophthalmoplegia in an adult patient. It concerns a novel variant that is responsible for decreased GMPR protein levels in patients' skeletal muscle, as well as in proliferating and quiescent cells. It is moreover linked to subtle changes in nucleotide homeostasis protein levels, while there is also evidence that it may be the cause of disturbed mtDNA maintenance in skeletal muscle [29]. Whether the absence of the GMPR gene in 6p22.3 deletion is associated with the hypotonia observed in the phenotype of this syndrome warrants further investigation.

The NUP153 gene (OMIM \#603,948) encodes nucleoporin 153 , a protein of the nucleoporin family. Nucleoproteins are the components of nuclear pore complexes (NPCs): these are membrane-embedded channels which mediate nuclear transport across the nuclear envelope [30]. Apart from their role as constituents of NPC components, nucleoporins have recently emerged as potential regulators of chromatin organization and transcription. Furthermore, their ability to regulate gene activity does not seem to be associated with NPCs and is not linked to mediating cargo translocation across the NPC central channel. Jacinto et al. demonstrated that depletion of NUP153 in mouse embryonic stem cells induces expression of developmental genes and results in early differentiation and loss of stem cell identity. The latter studies point to the possibility that nucleoporins have a direct role in controlling developmental transcription programs. They also indicate that NUP153 may play a chromatin-associated role in maintenance of stem cell pluripotency through functioning in mammalian epigenetic gene silencing $[31,32]$.

The KIF13A gene (OMIM \#605,433) encodes for the kinesin protein family member $13 \mathrm{~A}$, the kinesin proteins being ATP-dependent molecular motors moving along polarized microtubules in almost all cell types. They are hypothesized to have a significant role in neuronal signal transduction. It has been shown that the kinesin-3 motor 
KLP-4, the Caenorhabditis elegans homologue of human KIF13A and KIF13B, mediates axonal organization and cholinergic signaling and that strains with KLP-4 deletion had defects in locomotive signaling [33]. It is also suggested that $K I F 13 A$ is part of the protein-trafficking machinery and plays a role in the differential targeting of various proteins across the membrane of epithelial cells [34].

NHLRC1 (OMIM \#608,072) is a single-exon gene, located on chromosome $6 \mathrm{p} 22.3$, which encodes malin. Malin is a 395 amino acid protein that contains a RING and 6 NHL-repeat domains, thereby acting as an E3 ubiquitin ligase [35]. Malin interacts with laforin, and the complex of these two proteins plays a regulatory role in several cellular pathways, such as glycogen metabolism, proteolytic pathways, cellular stress response, mitochondrial homeostasis, and post-transcriptional gene regulation. Loss of function of malin and/or laforin affects neuronal function in various ways. Firstly, glycogen metabolism is impaired, which leads to accumulation of aberrant glycogen within the neuronal cells in the form of Lafora bodies, the hallmark of Lafora disease, a neurodegenerative disorder. It has been demonstrated in animal models that cells which lack malin or laforin are susceptible to autophagy impairment, increased endoplasmic reticulum stress, and reduced clearance of misfolded toxic proteins, the proteins being degraded through the ubiquitin proteasome system [36-38]. Apart from the neurodegenerative effects, lack of malin or laforin results in hyperexcitability of neuronal cells that manifests as seizures. Normal glycogen is necessary for the clearance of extracellular $\mathrm{K}$, given that the astrocytic $\mathrm{Na} / \mathrm{K}$-ATPase uses ATP generated from glucose 6-phosphate, the latter originating from glycogen breakdown. Conversely, nonclearance of extracellular $\mathrm{K}$ leads to neuronal hypersynchronization and burst firing, the crucial mechanism of seizure generation and propagation. Furthermore, normal glycogen synthesis and breakdown are of extreme importance for the homeostasis of glutamate, the main excitatory neurotransmitter in the brain. There is hence an important connection between the accumulation of abnormal glycogen and epilepsy, which urgently requires further investigation [39].

DEK (OMIM \#125,264) is a chromatin-remodeling gene that is expressed in most human tissues and is well known for its role in cancer biology and in autoimmune diseases. In vitro $D E K$ depletion decreases cellular proliferation; it also induces DNA damage, which subsequently leads to apoptosis, and down-regulates canonical Wnt/ $\beta$ catenin signaling, a molecular pathway crucial for learning and memory. There are few studies demonstrating a link between $D E K$ deletion and deficits in cognitive function. Notably, a study by Ghisays et al. demonstrated that the $D E K$ protein is abundantly expressed in healthy adult murine brains in corticolimbic structures, including the medial prefrontal cortex, amygdala, and hippocampus, which are linked to memory, learning, and neurogenesis [40]. To our knowledge, there is as yet no report in the literature associating lack of TPMT (OMIM \#187,680), the enzyme that catalyzes S-methylation of aromatic and heterocyclic sulphydryl compounds, with the 6p22.3 deletion phenotype.

The phenotype of our case is similar to the other 6 222-deletion cases described in the literature. Most cases present with craniofacial dysmorphisms, learning disorders, and developmental and intellectual disabilities. There is sufficient evidence to conclude that deficits in the $6 \mathrm{p} 22.3$ chromosomal region result in major disruption of pathways responsible for proper early development, especially of the central neural system, with severe impairment of specific intellectual and cognitive functions. Craniofacial dysmorphisms usually accompany and reflect the anomalies of the central neural system. The clinical features seen in our case could be attributed to the lower levels and reduced activity of crucial proteins encoded by the missing genes. Thus, ATX1 could be responsible for the speech delay, learning deficits, and low intelligence and developmental quotients. The $D E K$ gene defect might act synergically, affecting both memory and learning capabilities. Reduced function of GMPR could lead to hypotonia, cardiac defects, and skeletal abnormalities. Nevertheless, it is well established that any phenotype penetrance depends on the presence of modifiers found in the non-deleted alleles, regulatory regions, or other genes in different locations of the genome apart from those specific genes of the missing region that are mainly responsible.

The boy herein presented will be followed up for any reduction in his developmental delay or, on the other hand, any deterioration and/or newly presenting clinical symptoms or signs, such as seizures, since the missing NHLRC1 gene is associated with rapid and progressive adolescent-onset epilepsy. Accumulating data on such cases contribute to improvement in genetic counselling for rare and challenging hypo-chromosomal findings, which, today, are more frequently being detected thanks to constant advances in genetic analysis technologies. Moreover, enhanced accuracy in genotype-phenotype mapping will further aid in achieving ever better prognosis of outcome in the future.

\section{Conclusions}

6p22.3 deletions are rare and there is variability in the phenotype due to the variable sizes and locations of the deletions. With this report, we describe the phenotype of a case with 6 p22.3 deletion while presenting our review 
of the literature in an attempt to identify the implicated genes as well as their possible pathogenetic link with the clinical spectrum of this syndrome, as manifested in our case and other similar cases.

\begin{abstract}
Abbreviations
6p22.3 deletion: Deletion of p arm 22.3 locus of chromosome 6; array-CGH: Array comparative genomic hybridization; DQ: Developmental quotient; MRI: Magnetic resonance imaging; MYLIP: Myosin regulatory light chain interacting protein; GMPR: Guanosine monophosphate reductase; ATXN1: Ataxin-1; NUP153: Nucleoporin 153; KIF13A: Kinesin family member 13A; NHLRC1: NHL repeat containing E3 ubiquitin protein lipase 1; TPMT: Thiopurine S-methyltransferase; KDM1B: Lysine K-specific demethylase 1B; FISH: Fluorescence in situ hybridization; SNPs: Single nucleotide polymorphisms; ADHD: Attention-deficit/hyperactivity disorder; LDL: Low density lipoprotein; NPCs: Nuclear pore complexes; ATP: Adenosine triphosphate; DD: Developmental disability; ID: Intellectual disability; ASD: Autism spectrum disorder.
\end{abstract}

\section{Authors' contributions}

All authors contributed, read and approved the final manuscript.

\section{Funding}

There was no funding for this study.

\section{Availability of data and materials}

Data sharing is not applicable to this article as no datasets were generated or analysed during the current study.

\section{Declarations}

\section{Consent for publication}

Parental consent was obtained for the publication of this case report.

\section{Competing interests}

The authors declare that they have no competing interests.

\begin{abstract}
Author details
${ }^{1}$ Third Department of Obstetrics and Gynecology, National and Kapodistrian University of Athens, Medical School, Attikon Hospital, Athens, GR, Greece. ${ }^{2}$ Research Centre in Obstetrics and Gynecology, HSOGE, Athens, Greece. ${ }^{3}$ Vascular Biology, Molecular and Clinical Sciences Research Institute, St George's University of London, London, UK. ${ }^{4}$ Access To Genome P.C., Clinical Laboratory Genetics, Athens-Thessaloniki, Greece. ${ }^{5}$ Department of Clinical Therapeutics, National and Kapodistrian University of Athens, Medical School, Alexandra Hospital, Athens, Greece. ${ }^{6}$ Second Department of Pediatrics, Aglaia Kyriakou Hospital, Medical School, National \& Kapodistrian University of Athens, Athens, Greece. 'Department of Gynecology, General Hospital of Athens "G. Gennimatas", Athens, Greece. ${ }^{8}$ Neonatal Department, National and Kapodistrian University of Athens Medical School, Aretaieio Hospital, Athens, Greece. ${ }^{9}$ Department of Pediatrics, School of Medicine, Aristotle University of Thessaloniki, University General Hospital AHEPA, Thessaloniki, Greece.
\end{abstract}

Received: 29 December 2020 Accepted: 6 July 2021

Published online: 24 July 2021

\section{References}

1. Bremer A, Schoumans J, Nordenskjöld M, Anderlid BM, Giacobini M. An interstitial deletion of 7.1 Mb in chromosome band 6p22.3 associated with developmental delay and dysmorphic features including heart defects, short neck, and eye abnormalities. Eur J Med Genet. 2009;52(5):358-62. https://doi.org/10.1016/j.ejmg.2009.06.002.

2. Di Benedetto D, Di Vita G, Romano C, et al. 6p22.3 deletion: report of a patient with autism, severe intellectual disability and electroencephalographic anomalies. Mol Cytogenet. 2013;6(1):4. https://doi.org/10.1186/ 1755-8166-6-4.
3. Celestino-Soper PB, Skinner C, Schroer R, et al. Deletions in chromosome 6p22.3-p24.3, including ATXN1, are associated with developmental delay and autism spectrum disorders. Mol Cytogenet. 2012;5:17. https://doi. org/10.1186/1755-8166-5-17.

4. Barøy T, Misceo D, Strømme P, et al. Haploin sufficiency of two histone modifier genes on 6p22.3, ATXN1 and JARID2, is associated with intellectual disability. Orphanet J Rare Dis. 2013;8:3. https://doi.org/10.1186/ 1750-1172-8-3.

5. Davies AF, Olavesen MG, Stephens RJ, Davidson R, Delneste D, Van Regemorter N, Vamos E, Flinter F, Abusaad I, Ragoussis J. A detailed investigation of two cases exhibiting characteristics of the $6 p$ deletion syndrome. Hum Genet. 1996;98(4):454-9. https://doi.org/10.1007/s0043 90050239.

6. Zirn B, Hempel M, Hahn A, Neubauer B, Wagenstaller J, Rivera-Bruguès N, Strom TM, Köhler A. Polyneuropathy, scoliosis, tall stature, and oligodontia represent novel features of the interstitial $6 p$ deletion phenotype. Am J Med Genet A. 2008;146A(22):2960-5. https://doi.org/10.1002/ajmg.a. 32536.

7. Izu A, Yanagida H, Sugimoto K, Fujita S, Okada M, Takemura T. Focal segmental glomerulosclerosis and partial deletion of chromosome $6 \mathrm{p}$ : a case report. Clin Nephrol. 201 1;76(1):64-7. https://doi.org/10.5414/cn106587.

8. Van Swaay E, Beverstock GC, van de Kamp JJ. A patient with an interstitial deletion of the short arm of chromosome 6. Clin Genet. 1988;33(2):95101. https://doi.org/10.1111/j.1399-0004.1988.tb03418.x.

9. Davies AF, Mirza G, Sekhon G, Turnpenny P, Leroy F, Speleman F, Law C, van Regemorter N, Vamos E, Flinter F, Ragoussis J. Delineation of two distinct 6p deletion syndromes. Hum Genet. 1999;104(1):64-72. https:// doi.org/10.1007/s004390050911.

10. Palmer CG, Bader P, Slovak ML, Comings DE, Pettenati MJ. Partial deletion of chromosome 6p: delineation of the syndrome. Am J Med Genet. 1991:39:155-60.

11. Plaja A, Vidal R, Soriano D, Bou X, Vendrell T, Mediano C, Pueyo JM, Labrana X, Sarret E. Terminal deletion of $6 \mathrm{p}$ : report of a new case. Ann Genet. 1994;37:196-9.

12. Colmant C, Brisset S, Tachdjian G, et al. Interstitial deletion 6p22.3-p24.3 characterized by CGH array in a foetus with multiple malformations. Prenat Diagn. 2009;29(9):908-10. https://doi.org/10.1002/pd.2306.

13. Reid CS, Stamberg J, Phillips JA. Monosomy for distal segment $6 \mathrm{p}$ : clinical description and use is localising a region important for expression of Hageman factor [abstract]. Pediatr Res. 1983;40:3127.

14. Zurcher VL, Golden WL, Zinn AB. Distal deletion of the short arm of chromosome 6. Am J Med Genet. 1990;35:261-5.

15. Law CJ, Fisher AM, Temple IK. Distal $6 p$ deletion syndrome: a report of a case with anterior chamber eye anomaly and review of published reports. J Med Genet. 1998;35:685-9.

16. Mirza G, Williams RR, Mohammed S, Clark R, Newbury-Ecob R, Baldinger S, Flinter F, Ragoussis J. Refined genotype-phenotype correlations in cases of chromosome $6 p$ deletion syndromes. Eur J Hum Genet. 2004; 12:718-28.

17. Lin RJ, Cherry AM, Chen KC, Lyons M, Hoyme HE, Hudgins L. Terminal deletion of $6 p$ results in a recognizable phenotype. Am J Med Genet A. 2005;136:162-8.

18. Jalal SM, Macias VR, Roop H, Morgan F, King P. Two rare cases of $6 p$ partial deletion. Clin Genet. 1989;36:196-9.

19. Flöttmann R, Wagner J, Kobus K, Curry CJ, Savarirayan R, Nishimura G, Yasui N, Spranger J, Van Esch H, Lyons MJ, DuPont BR, Dwivedi A, Klopocki E, Horn D, Mundlos S, Spielmann M. Microdeletions on 6p22.3 are associated with mesomelic dysplasia Savarirayan type. J Med Genet. 2015;52(7):476-83. https://doi.org/10.1136/jmedgenet-2015-103108.

20. Ladinsky HT, Elizalde A, Schickler R, Dees PB, Crenshaw ML, Sleasman JW. Hypereosinophilic syndrome and hemimelia in a patient with chromosome 6p22.3 deletion. Pediatr Allergy Immunol. 2014;25(5):500-3. https:// doi.org/10.1111/pai.12213.

21. Spielmann M, Lupiáñez DG, Mundlos S. Structural variation in the 3D genome. Nat Rev Genet. 2018;19(7):453-67. https://doi.org/10.1038/ s41576-018-0007-0.

22. Gehrking KM, Andresen JM, Duvick L, Lough J, Zoghbi HY, Orr HT. Partial loss of Tip60 slows mid-stage neurodegeneration in a spinocerebellar ataxia type 1 (SCA1) mouse model. Hum Mol Genet. 2011;20(11):2204-12. https://doi.org/10.1093/hmg/ddr108. 
23. Matilla A, Roberson ED, Banfi S, et al. Mice lacking ataxin-1 display learning deficits and decreased hippocampal paired-pulse facilitation. J Neurosci. 1998;18(14):5508-16. https://doi.org/10.1523/JNEUROSCI.1814-05508.1998.

24. Rizzi TS, Arias-Vasquez A, Rommelse N, et al. The ATXN1 and TRIM31 genes are related to intelligence in an ADHD background: evidence from a large collaborative study totaling 4,963 subjects. Am J Med Genet B Neuropsychiatr Genet. 2011;156(2):145-57. https://doi.org/10.1002/ ajmg.b.31149.

25. Olsson PA, Bornhauser BC, Korhonen L, Lindholm D. Neuronal expression of the ERM-like protein MIR in rat brain and its localization to human chromosome 6. Biochem Biophys Res Commun. 2000;279(3):879-83. https://doi.org/10.1006/bbrc.2000.4028.

26. Bornhauser BC, Johansson C, Lindholm D. Functional activities and cellular localization of the ezrin, radixin, moesin (ERM) and RING zinc finger domains in MIR. FEBS Lett. 2003;553(1-2):195-9. https://doi.org/10.1016/ s0014-5793(03)01010-x.

27. Olsson PA, Korhonen L, Mercer EA, Lindholm D. MIR is a novel ERM-like protein that interacts with myosin regulatory light chain and inhibits neurite outgrowth. J Biol Chem. 1999;274(51):36288-92. https://doi.org/ 10.1074/jbc.274.51.36288.

28. Lindholm D, Bornhauser BC, Korhonen L. Mylip makes an Idol turn into regulation of LDL receptor. Cell Mol Life Sci. 2009;66(21):3399-402. https://doi.org/10.1007/s00018-009-0127-y.

29. Sommerville EW, Dalla Rosa I, Rosenberg MM, et al. Identification of a novel heterozygous guanosine monophosphate reductase (GMPR) variant in a patient with a late-onset disorder of mitochondrial DNA maintenance. Clin Genet. 2020;97(2):276-86. https://doi.org/10.1111/cge. 13652.

30. Bilir \$̧, Kojidani T, Mori C, et al. Roles of Nup133, Nup153 and membrane fenestrations in assembly of the nuclear pore complex at the end of mitosis. Genes Cells. 2019;24(5):338-53. https://doi.org/10.1111/gtc. 12677.

31. Jacinto FV, Benner C, Hetzer MW. The nucleoporin Nup153 regulates embryonic stem cell pluripotency through gene silencing. Genes Dev. 2015;29(12):1224-38. https://doi.org/10.1101/gad.260919.115.

32. Leone L, Colussi C, Gironi K, et al. Altered Nup153 expression impairs the function of cultured hippocampal neural stem cells isolated from a mouse model of Alzheimer's disease. Mol Neurobiol. 2019;56(8):5934-49. https://doi.org/10.1007/s12035-018-1466-1.

33. Magaletta ME, Perkins KJ, Deuchler CP, Pieczynski JN. The Kinesin-3 motor, KLP-4, mediates axonal organization and cholinergic signaling in Caenorhabditis elegans. FASEB Bioadv. 2019;1(7):450-60. https://doi.org/ 10.1096/fba.2019-00019.

34. Xu X, Pan M, Gasiewicz AE, Li R, Kuo SM. Human and mouse microarraysguided expression analysis of membrane protein trafficking-related genes in MDCK cells, a canine epithelial model for apical and basolateral differential protein targeting. Biochim Open. 2017;4:119-26. https://doi. org/10.1016/j.biopen.2017.04.002.

35. Singh S, Suzuki T, Uchiyama A, et al. Mutations in the NHLRC1 gene are the common cause for Lafora disease in the Japanese population. J Hum Genet. 2005;50(7):347-52. https://doi.org/10.1007/s10038-005-0263-7.

36. Sullivan MA, Nitschke S, Steup M, Minassian BA, Nitschke F. Pathogenesis of Lafora disease: transition of soluble glycogen to insoluble polyglucosan. Int J Mol Sci. 2017;18(8):1743. https://doi.org/10.3390/ijms180817 43.

37. Nitschke F, Ahonen SJ, Nitschke S, Mitra S, Minassian BA. Lafora disease - from pathogenesis to treatment strategies. Nat Rev Neurol. 2018;14(10):606-17. https://doi.org/10.1038/s41582-018-0057-0.

38. Parihar R, Rai A, Ganesh S. Lafora disease: from genotype to phenotype. J Genet. 2018;97(3):611-24.

39. Gentry MS, Guinovart JJ, Minassian BA, Roach PJ, Serratosa JM. Lafora disease offers a unique window into neuronal glycogen metabolism. J Biol Chem. 2018;293(19):7117-25. https://doi.org/10.1074/jbc.R117.803064.

40. Ghisays V, Nguyen ET, Streicher J, et al. Neuroanatomical distribution of DEK protein in corticolimbic circuits associated with learning and memory in adult male and female mice. Neuroscience. 2018;371:254-67. https://doi.org/10.1016/j.neuroscience.2017.11.025.

\section{Publisher's Note}

Springer Nature remains neutral with regard to jurisdictional claims in published maps and institutional affiliations.
Ready to submit your research? Choose BMC and benefit from:

- fast, convenient online submission

- thorough peer review by experienced researchers in your field

- rapid publication on acceptance

- support for research data, including large and complex data types

- gold Open Access which fosters wider collaboration and increased citations

- maximum visibility for your research: over $100 \mathrm{M}$ website views per year

At BMC, research is always in progress.

Learn more biomedcentral.com/submissions 